\title{
Goldmark's Wild Amazons Drama and Exoticism in the Penthesilea Overture
}

\author{
Jane ROPER \\ Royal College of Music \\ Prince Consort Road, London SW7 2BS, United Kingdom \\ E-mail: jane.roper@rcm.ac.uk
}

(Received: March 2016; accepted: June 2016)

\begin{abstract}
Goldmark was the first of several composers to write a work based on Heinrich von Kleist's controversial play, Penthesilea. Early critical opinion about the overture was divided. Hanslick found it distasteful, whereas others were thrilled by Goldmark's powerful treatment of the subject. Composed in 1879, during the $1880 \mathrm{~s}$ Penthesilea became established in orchestral repertoire throughout Europe and America. The overture represents the conflict of violence and sexual attraction between the Queen of the Amazons and Achilles. Exoticism in the play is achieved by contrasting brutal violence, irrational behaviour and extreme sensual passion. This is recreated musically by drawing on topics established in opera. Of particular note is the use of dissonance and unexpected modulations, together with extreme rhythmic and dynamic contrast. A key feature of the music is the interplay between military rhythms representing violence and conflict, and a legato, rocking theme which suggests desire and sensuality.
\end{abstract}

Keywords: Goldmark, Exoticism, Penthesilea Overture

The Penthesilea Overture, op. 31, is arguably Carl Goldmark's most controversial work. Its content is provocative. Consider first of all the subject matter: Goldmark transports us to the battlefield of Troy in the twelfth century BC. Penthesilea, Queen of the Amazons, a terrifying, ferocious warrior tribe of women, gallops onto the scene with her retinue. The Amazons are bloodthirsty and hungry for sex, anticipating the men they will capture to enact their fertility ritual. Passions run high when they meet Achilles and his troops. The scene is tense. We can feel the heat in Goldmark's music. It bursts with raw, savage energy. Accents, harsh 
timbres and dissonant chords make us sit up and listen. Penthesilea grabs us and draws us in. We are then engulfed in her erotic dreams in the atmosphere of the sensual, fragrant Rose Festival. Alluring, winding melodies played by wind instruments alternate with seductive, legato string passages. Finally, the destructive power of irreconcilable love overtakes the scene and we are back in conflict and ultimately, death. This was a plot guaranteed to arouse, to provoke and to shock and it certainly had this effect on some of the earliest recipients of Goldmark's new overture in 1880.

We must imagine ourselves in Vienna in the company of Eduard Hanslick and the surgeon and music enthusiast, Theodor Billroth in the year 1880. They have just performed the piano duet version of the overture and are reeling from the effect it had on them. A few days later, immediately after the Viennese premiere, the following review by Hanslick appears in the Neue Freie Presse in Vienna:

Out of curiosity and against our better judgment, we played through the work in the arrangement for four hands in advance, an operation, which we would only recommend to anybody after hearing the orchestral performance. Right from the first two chords, we felt as if we had fallen off the stool, for in our long experience with every year more dissonant practice, we have scarcely known someone enter the house through such a door. It sounds like a sharp whiplash with the accompanying outcry of the victim; Wagner's Valkyries enter more considerately than these Goldmarkian Amazons! ${ }^{1}$

It was common practice that full scores and piano arrangements of new works would be published around the time of the first performance. Audiences could thus get to know a piece before they heard it in the concert hall. ${ }^{2}$ Familiarity, through having seen a title in print, as well as by playing it through, could encourage audience attendance at concerts at a time when orchestral concerts were difficult to finance. This was often done, especially in England, where new repertoire mostly

1. Eduard Hanslick, "Hofoperntheater: Concerte," Neue Freie Presse Nr. 5847 (7 December 1880, morning edition), 2. This is a revised translation of a passage quoted by David Brodbeck in "Poison-Flaming Flowers from the Orient and Nightingales from Bayreuth: On Hanslick's Reception of the Music of Goldmark," in Rethinking Hanslick: Music, Formalism and Expression, ed. Nicole Grimes, Siobhán Donovan and Wolfgang Marx (Rochester, NY: University of Rochester Press, 2013), 132-159. Original German text: "Gleich bei den ersten zwei Akkorden glaubten wir vom Stuhle zu fallen, denn kaum war es uns in unserer langen, mit jedem Jahre dissonanzreicheren Praxis vorgekommen, daß jemand mit einer solchen Thür ins Haus fällt. Es klingt wie ein scharfer Geißelhieb sammt den dazugehörigen Aufschrei des Getroffenen; Wagners Walküren springen rücksichtsvoller herein, als diese Goldmarkschen Amazonen."

2. The score, parts and piano arrangement of Penthesilea was advertised by Schott in German newspapers as early as October 1879. See, for example, Signale für die musikalische Welt 37/53 (October 1879 ) 847. Performance of the work by the Vienna Philharmonic in the 1879/80 season was announced in the Viennese daily press from 12 October 1879. See, for example, Wiener Zeitung No. 238 (12 October 1879), 3-4 and Wiener Sonn- und Montags-Zeitung 17/82 [2]. 
came from abroad, as can be seen in early editions of the Musical Times. ${ }^{3}$ According to a letter to his brother Leo in America, Goldmark hoped that this would be the case, ${ }^{4}$ but as Hanslick observed, it was not necessarily advisable! Hanslick and Billroth were simply not ready for the dissonances as they hit them straight off the page and felt them under their fingers. Hanslick's implication is that their impressions might have been more sympathetic had they merely heard, rather than performed the opening chords for their first encounter with Penthesilea. The orchestration changes the perception of the dissonance, and the orchestral timbre tends to have a stronger impact on the listener than the harmony at the opening.

The quality of piano duet arrangements was variable, and this one is not particularly special. The very best piano duets of Goldmark's orchestral works, such as Sakuntala, stand up as concert works in their own right. ${ }^{5}$ The arrangement of Penthesilea, although a competent and mostly accurate adaptation of the score, does not capture the more subtle spirit of the work. This is partly because the effectiveness of the work depends on "Klangwirkung". ${ }^{6}$ Goldmark achieves this in Penthesilea through careful and complex orchestral colouring and from the sound dimensions, from the use of solo instruments to full, massive scoring and antiphonal effects. His dependence on "amount of sound" for musical impact is crucial to the work. ${ }^{7}$ Unlike the Sakuntala duet and piano arrangements from The Queen of Sheba, which almost certainly were made by Goldmark himself, the Penthesilea duet might be the work of one of the publisher Schott's in-house arrangers, who would have been working on numerous scores by a wide range of composers. If this is not the case, then it can only be described as an arrangement over which Goldmark took little care or found difficult. ${ }^{8}$ It is telling that Liszt, around the same time, commented on the difficulty of "reducing the marvellous colouring"

3. Penthesilea was first announced in The Musical Times and Singing Class Circular 21/443 (1 January 1880), 6. The piano duet reduction was advertised at the fairly expensive price of 12 shillings alongside various piano arrangements of Sakuntala. Later editions of Musical Times mention the availability of orchestral score and parts.

4. Letter to his brother Leo Goldmark in the USA, 10 December 1880. Leo Baeck Institute. https://archive.org/stream/goldmarkfamilyco01gold\#page/n511/mode/1up (accessed 3 November 2015). ertoire.

5. I am grateful to Tihamér Hlavacsek for sharing with me his insights on the Goldmark piano duet rep-

6. Goldmark was always intent on showing individuality as a composer and on "Klangwirkung," which is connected to the ability to express oneself in music. He had explained this in his Essay on Musical Progress (1860) and it remained his philosophy throughout his life: "Every composer should give individuality full scope in their works [...] and find a trace, a spark of themselves". Blätter für Musik Theater und Kunst 4/65 (14 August 1860), 257. See Johann Hofer, Carl Goldmark. Komponist der Ringstrassenzeit (Vienna: Steinbauer, 2015), 71. This belief was restated by Goldmark's nephew, Rubin in "Goldmark," in The Looker-On 4 (April 1897), 278-284.

7. See Leonard Ratner, Romantic Music. Sound and Syntax (New York: Schirmer, 1992), 9.

8. Marc-André Roberge suggests that it was standard practice for composers to create their own piano transcriptions. See Marc-André Roberge, "From Orchestra to Piano: Major Composers as Authors of Piano Reductions of Other Composers' Works," Notes 49/3 (March 1993), 926. However, the variability in quality amongst transcriptions of Goldmark's works leads to some doubt about this in his case. Goldmark himself recognised the limitations of the Penthesilea arrangement. In a letter to his brother Leo (Vienna 10 December 1880; Leo Baeck Institute) he observed that it had contributed to the spread of bad rumours about the overture. 
of orchestral scores in piano transcriptions and, earlier in his career, he had even given up transcribing his own symphonic poem, Tasso.

\section{Performance history}

Goldmark's Overture to Penthesilea is based on a play by Heinrich von Kleist from 1808. It was composed at Gmunden during the summer of 1878 . This was shortly after Goldmark had visited Italy with Brahms and Billroth. Goldmark had stayed in Rome for the production of his opera, The Queen of Sheba, whilst Brahms and Billroth continued their tour. The final autograph manuscript is dated Gmunden 21 October $1878 .{ }^{10}$ It was premiered in Budapest on 12 November $1879 .{ }^{11}$ Goldmark was in Pest at the time for the wedding of Sydi, his sister Johanna's daughter Sidonie Friedmann, who married Ignatz Ripper on 11 November 1879. Although he does not mention the premiere in his letter to Leo Goldmark, where he reports on the wedding, he would surely have been present at the concert and probably conducted the work. Penthesilea was received well, in line with contemporary reviews of Goldmark in Budapest at the time. József Harrach, wrote that

Goldmark incorporates great dramatic strength; purer and clearer than in his previous works. The lovely working out, the consequent unfolding and development of the themes gives the work a feeling of unity. Goldmark's feverish passion is calmer in this work and the sentimentality is not so painful. ${ }^{12}$

Performances in America, Amsterdam and London followed shortly after the Budapest premiere. The New York premiere under Leopold Damrosch would have been instigated by Goldmark's brother, Leo, who had emigrated from Hungary to the United States and was now a wealthy businessman. ${ }^{13} \mathrm{He}$ maintained close contact with the family back in Hungary, but especially with Carl in Vienna, for whom he acted as an agent. Leo Goldmark apparently knew all the German musicians who came to America and was an important link between the continent and the New World. American concert life, still in its infancy had little prejudice towards the introduction of new works, even those with challenging subjects, such as Penthesilea. The frequency of repeat performances suggests that the work soon found a place in the repertoire, although it never became as popular as Sakuntala,

9. See Ratner, Romantic Music, 5.

10. Országos Széchényi Könyvtár, Budapest, Ms. mus. 6.483.

11. Incorrect information is given in Hofer, Goldmark, 173. See list of early performances in Table 1.

12. Pesti Napló 30/272 (13 November 1879).

13. The dispatch of the score is mentioned in a letter from Carl Goldmark to his brother dated Gmunden 3 November 1879. Leo Baeck Institute. 
the Rustic Wedding Symphony or the Violin Concerto. ${ }^{14}$ There is some uncertainty regarding the first performance in the United States. Contemporary sources mention that it had been premiered in New York. ${ }^{15}$ However, Theodore Thomas, the great showman conductor in American concert life at the time, claimed to have introduced the work a day earlier with his Chicago Orchestra in Cincinnati. ${ }^{16}$ There was intense rivalry between Thomas and Damrosch and this included the prestige of premiering new works. Only a few months before, the more self-confident and popular Thomas had returned to the New York scene, apparently to save the New York orchestra from collapse. ${ }^{17}$ It is therefore quite possible that he could have had a copy of the score and that the premiere really did take place at the Cincinnati concert. Incidentally, with some modesty, perhaps because he was feeling the pressure of some bad performances of The Queen of Sheba in Germany and dreading forthcoming rehearsals in Dresden and Berlin, Goldmark wrote to his brother Leo that if Damrosch did not like Penthesilea, he should feel no obligation to perform it out of friendship. ${ }^{18}$

In England, where concert-life was also undergoing rapid expansion, the premiere of Penthesilea fell neatly into the programme of events for 1880, even if it created a relatively low impact. After the first performance in London under Wilhelm Ganz (1833-1914), the work is mentioned in concert reviews, but without any detailed comment. The main attraction at that concert was the presence of Saint-Saëns, who was playing his D-minor Piano Concerto for the first time in England. ${ }^{19}$

Hans Richter, whose first performance of the work in England was at the Crystal Palace in London in May 1881, had more success in bringing Penthesilea to the attention of the public, although again there was little excitement about it in the press. The Musical Times reported that it "contains some bright and effective orchestral passages, but does not at first sight appear in an important or even a distinctive light". ${ }^{20}$ In England, as in America, there was a forward-thinking approach to concert repertoire. The Richter concerts at the Crystal Palace had a reputation for being pioneering and were quite different from concerts on the con-

14. See Kate Hevner Mueller, Twenty-Seven Major American Symphony Orchestras: A History and Analysis of their Repertoires. Seasons 1842-43 through 1969-70 (Bloomington: Indiana University Studies, 1973).

15. Programme for Boston Symphony Orchestra Concert 14/15 March 1902. Historical and analytical notes by Philip Hale.

16. Theodore Thomas (1835-1905). Theodore Thomas, A Musical Autobiography, ed. George Upton (Chicago: McClurg, 1905), 364.

17. See Ezra Schabas, Theodore Thomas. America's Conductor and Builder of Orchestras, 1835-1905 (Urbana and Chicago: University of Illinois Press, 1989), 79-81.

18. Letter to Leo Goldmark, 3 November 1879.

19. See Wilhelm Ganz, Memories of a Musician (London: Murray, 1913), 141. A further aspect of this concert, which detracted from the premiere of Penthesilea, was the indisposition of the famous tenor Mr Sims Reeves, who had just had an operation. Incidentally, Saint-Saëns's Piano Concerto was frequently coupled with Penthesilea on concert programmes in England and America.

20. Musical Times 22/460 (1 June 1881), 301. 
tinent in terms of repertoire, according to one German author. ${ }^{21}$ Organisers were happy to programme several new works in one season and even within a single concert, without the fear of losing precious subscriptions from patrons.

The success and repeated performances of Penthesilea in the United States and England can be attributed to a strong network of German and Austrian musicians who had emigrated, but who as young men had known Goldmark. Amongst them were the conductors Wilhelm Ganz, Leopold Damrosch, George Henschel and Wilhelm Gericke, some of whom were still in contact with him. ${ }^{22}$ However, the decisive figure who galvanised this support was Hans Richter, his Hungarian compatriot. Richter it was too, who ensured that the work was performed in Vienna. ${ }^{23}$ Richter revived Penthesilea in England in the 1900s, and brought Goldmark's music to the attention of the young conductor, Henry Wood. Thus it was that Penthesilea would remain in the repertoire in England longer than anywhere else in the world.

If Goldmark had become known as the "Makart of music"24 through his monumental The Queen of Sheba opera, Penthesilea did not have the same effect for him. The early responses to Penthesilea were in most cases lukewarm and some were even hostile. English audiences seemed not to understand the subtleties in its exploration of emotional states or recognise the challenges it offered, neither in terms of the use of Kleist's play, nor musically in terms of dissonances. In spite of the 1886 performances in northern England, Penthesilea had clearly been forgotten by 1905, when it was announced as new repertoire at a Manchester Hallé concert conducted by Richter. ${ }^{25}$ Hanslick and Wolf's hostile reactions did not stem from lack of comprehension of the music, although they both misunderstood Goldmark as a person. Hanslick had become a supporter of Brahms and opponent of Wagner and had no time for music that fell between the two camps. Wolf, on the other hand, an ardent Wagnerite, was young, hot-headed, desperate to achieve success himself and jealous of Goldmark's good rapport with Hans Richter. His report on the work in 1884 for the Wiener Salonblatt takes the form of an overheard monologue. Commenting on the concert programmes of Hans Richter, he said

21. See Ferdinand Präger, "London," Neue Zeitschrift für Musik 76/14 (26 March 1880), 149.

22. See, for instance, George Henschel, Musings of a Musician (New York: Macmillan, 1913), 126. Around 1886 Gericke was in correspondence with Goldmark and also with Hans Richter. Letters in Wilhelm Gericke papers, Houghton Library, Harvard University.

23. Richter was still performing Penthesilea in 1893 as two letters of thanks from Goldmark testify. April 1893, before 10 of the month, a performance in Vienna, at which Goldmark was present, apparently a wonderful [wirklich großartige] performance. Shortly before 26 June 1893, a performance in London, which Richter had evidently reported to him as having been a great success. Letters from the Hans Richter Collection, Liszt Museum Budapest, R-Ep27 (10 April 1893) and R-Ep28 (26 June 1893).

24. Hans Makart (1840-1884) was a popular artist in Vienna at the time. He had a taste for bold colours and spectacle and was responsible for the interior design of several fashionable Viennese villas.

25. Musical Times 46/744 (1 February 1905), 121. 
Penthesilea. A wonderful subject for setting musically. But the composer's talent is not equal to the greatness of the substance. Only a Makart could realise it in colour, only a Liszt or a Berlioz in music. ${ }^{26}$

Wolf had some reason to be bitter since his own Penthesilea, his first largescale orchestral work was rejected by Richter, rather unceremoniously. The resemblance to Goldmark's composition is striking, particularly at the opening, but Wolf's Penthesilea is altogether more extreme in terms of instrumentation, length and structural complexity. It is therefore not surprising that it was first performed as late as 1903, and then only in an abbreviated and re-orchestrated version. ${ }^{27}$

By the turn of the century a more perceptive understanding of Goldmark's Penthesilea emerged. The composer began to be aligned with the late, rather than mid-nineteenth-century Vienna, with trends towards secession and particularly the emphasis on erotic and exotic subjects. The non-European, oriental aspect of the character of Penthesilea and the extraordinary customs of the Amazons were celebrated, even over-dramatized by Americans. Philip Hale's essay for Boston Symphony Orchestra concert programmes of 1902 brings in as much oriental material as possible in support, but crucially without reference to the actual music. ${ }^{28}$

In Vienna there was no hurry to introduce Goldmark's new work to the public. Conditions were very different from either America or England, where concert life was in its infancy. The established order, with its conventions, prejudices and acute sense of fashion and taste, was difficult to break through. Although the Vienna Philharmonic accepted the work for performance in 1879, the Viennese premiere took place over a year later. Exactly how Goldmark's Penthesilea would be received was uncertain, especially given rumours put about by members of the orchestra that the work was difficult. ${ }^{29}$ Nevertheless, Hans Richter was supportive of Goldmark's music and it eventually went ahead. ${ }^{30}$ Hanslick's review, as discussed earlier, was negative, others echoed the reception in England. The Neue Zeitschrift für Musik commented on the wild and tragic content, which was largely attributable to its particularly exciting and bold harmonic development and the instrumentation. ${ }^{31}$ Goldmark himself, evidently relieved that it had finally taken

26. Leopold Spitzer and Isabella Sommer (ed.), Hugo Wolfs Kritiken im Wiener Salonblatt (Vienna: Musikwissenschaftlicher Verlag, 2002), vol. 1, 56-58 and vol. 2, 51.

27. See Christopher Fifield, True Artist and True Friend: A Biography of Hans Richter (Oxford: Clarendon Press, 1993), 231-233.

28. Programme for 14/15 March 1902, Boston. Historical and analytical notes by Philip Hale.

29. Letter to Goldmark's brother Leo in the United States, dated Wien 10 December 1880. Leo Baeck Institute.

30. See Fifield, Richter, 161. Reports in the press indicate that the performance was announced, but delayed at least once during the 1880 concert season. Dvořà's Serenade for Wind apparently suffered the same fate in that season. Signale für die musikalische Welt 38/30 (April 1880), 472.

31. Neue Zeitschrift für Musik 77/1 (1 January 1881), 8. 
place, wrote to his brother that it had met with exceptional success, which was not at all to be expected in Vienna. ${ }^{32}$

The dearth of performances of Penthesilea on the European continent may be explained by the response to the work in Vienna and the conservative tastes of audiences and conductors, but also to Goldmark's reputation for composing music that was technically challenging for performers. Moreover, around 1879-1881, earlier Goldmark works, such as Sakuntala (1865) and the Rustic Wedding Symphony (1876) still counted amongst "Novitäten" (novelties) in Germany, according to the Neue Zeitschrift für Musik. Premieres of The Queen of Sheba (1875) were still taking place when Penthesilea was a new work and they inevitably involved complex preparation, often overseen by the composer himself. ${ }^{33}$ Brahms commented to Elisabeth Herzogenberg on how The Queen of Sheba consumed Goldmark's time, taking him away from Gmunden and Vienna for long periods. ${ }^{34}$ This must have contributed to the impression that the overture would be difficult, in many respects unjustly. Whilst Goldmark was busy with stagings of the opera, his interest was probably not particularly focused promoting a new overture. $\mathrm{He}$ was reported to be in Berlin for rehearsals of The Queen of Sheba in early December 1879. ${ }^{35}$ Penthesilea also came on the scene around the same time as Brahms' Tragic Overture, a work which rapidly achieved high acclaim by the critics, detracting attention from Goldmark's latest overture.

TABLE 1 Significant Performances of Goldmark's Penthesilea

\begin{tabular}{|l|l|l|l|}
\hline Date & Orchestra & Venue/ City & Conductor \\
\hline 12 November 1879 & Budapest Philharmonic & $\begin{array}{l}\text { Budapest, Grosser } \\
\text { Redoutensaal }\end{array}$ & Carl Goldmark \\
\hline 3 December 1879 & $\begin{array}{l}\text { Chicago Orchestra } \\
\text { or Theodore Thomas } \\
\text { Orchestra }\end{array}$ & Cincinnati Music Hall & Theodore Thomas ${ }^{37}$ \\
\hline $\begin{array}{l}\text { 4, 6 December 1879 } \\
\text { 11, 13 March 1880 }\end{array}$ & New York Symphony & $\begin{array}{l}\text { Steinway Hall, } \\
\text { New York }\end{array}$ & Leopold Damrosch \\
\hline
\end{tabular}

32. Letter to Goldmark's brother Leo 10 December 1880. Leo Baeck Institute.

33. Neue Zeitschrift für Musik 75/39 (19 September 1879), comments on the difficulty of the music, mentioning that Goldmark was in Leipzig at the time to oversee the rehearsals of the opera.

34. Letter of 22 November 1877. See Max Kalbeck (ed.), Brahms. The Herzogenberg Correspondence, trans. Hannah Bryant (London: John Murray, 1909), 28.

35. Neue Zeitschrift für Musik 76/50 (5 December 1879), 516.

36. [No author], Goldmark Károly 1830-1930 május 18 (Budapest: Fővárosi Nyilvános Könyvtár, 1930), 33.

37. Chicago Symphony Orchestra archives. Penthesilea is not amongst the US premieres at Chicago, but three other later concert works by Goldmark were directed there for the first time by Theodore Thomas. http:// cso.org/globalassets/about/rosenthal-archives/pdfs/us_premieres.pdf (accessed 2 July 2015).

38. New York Philharmonic Archives. http://archives.nyphil.org/ (accessed 14 April 2015). There were further repeat performances by popular request in April 1880. See Signale für die musikalische Welt 38/25 (March 1880), 396. 
TABle 1 Continued

\begin{tabular}{|l|l|l|l|}
\hline Date & Orchestra & Venue/ City & Conductor \\
\hline 16 December 1879 & $\begin{array}{l}\text { Russian Musical } \\
\text { Society }\end{array}$ & Moscow & Nikolai Rubinstein? ${ }^{39}$ \\
\hline 21 December 1879 & $\begin{array}{l}\text { Städtisches } \\
\text { Curcorchester, Extra- } \\
\text { Symphonisches- } \\
\text { Concert }\end{array}$ & Wiesbaden & Louis Lüstner ${ }^{40}$ \\
\hline 14 January 1880 & Parkorkest & Parkzaal, Amsterdam & Willem Stumpff ${ }^{41}$ \\
\hline $\begin{array}{l}\text { 20 January, 17 } \\
\text { February 1880 }\end{array}$ & $\begin{array}{l}\text { New York } \\
\text { Philharmonic }\end{array}$ & Brooklyn & Theodore Thomas \\
\hline 14 April 1880 & Königliche Capelle & Berlin & Wilhelm Taubert ${ }^{43}$ \\
\hline 1 May 1880 & Ganz's Orchestra & St James' Hall London & Wilhelm Ganz ${ }^{44}$ \\
\hline Late June 1880 & $\begin{array}{l}\text { Curcapelle } \\
\text { Symphonie-concerte im } \\
\text { Posthof, Karlsbad }\end{array}$ & August Labitzky \\
\hline 15 September 1880 & $\begin{array}{l}\text { Königliche Concert- } \\
\text { Kapelle }\end{array}$ & Belvedere, Dresden & Bernhard Gottlöber ${ }^{46}$ \\
\hline November 1880 & Mainzer Capelle & Mainz & Emil Steinbach ${ }^{47}$ \\
\hline 5 December 1880 & Vienna Philharmonic & Hofoper, Vienna & Hans Richter \\
\hline 19 May 1881 & $\begin{array}{l}\text { Unnamed: 'Richter } \\
\text { Concerts' }\end{array}$ & Crystal Palace, London & Hans Richter ${ }^{48}$ \\
\hline 3 December 1881 & $\begin{array}{l}\text { Boston Symphony } \\
\text { Orchestra }\end{array}$ & Boston & Georg Henschel ${ }^{49}$ \\
\hline 12 January 1885 & Budapest Philharmonic & Budapest & Sándor Erkel ${ }^{50}$ \\
\hline
\end{tabular}

39. Signale für die musikalische Welt 38/4 (January 1880), 55.

40. Neue Zeitschrift für Musik 75/51 (12 December 1879), 527; Musikalisches Wochenblatt 11/2 (2 January 1880), 20.

41. Neue Zeitschrift für Musik 76/9 (20 February 1880), 98. On Stumpff, see Darryl Cressman, Building Musical Culture in Nineteenth-Century Amsterdam: The Concertgebouw (Amsterdam: Amsterdam University Press, 2016), 60.

42. Neue Zeitschrift für Musik 76/10 (27 February 1880), 106.

43. Neue Zeitschrift für Musik 76/18 (23 April 1880), 191.

44. Announced in Musical Times 21/447 (1 March 1880), 132.

45. Goldmark was in residence taking a cure at Karlsbad at the time and was present at the concert. See Joseph Engel, 'Carlsbad', Musikalisches Wochenblatt 11/30 (16 July 1880), 363.

46. Musikalisches Wochenblatt 11/41 (1 October 1880), 487. Penthesilea was performed again in Dresden by the same forces shortly before 8 September 1882. See Neue Zeitschrift für Musik 78/37 (8 September 1882), 398.

47. Signale für die musikalische Welt 38/67 (November, 1880), 1066. This performance is interesting in that Mainz was where Penthesilea (and many other Goldmark works) had been published by Schott. The report suggests that the work did not go down well here. This is perhaps due to the inexperience of the orchestra, which had been a modest affair until 1876 when it received funding from the legacy of the publisher Franz Schott. See Xv. Z., "Correspondenzen. Mainz,” Neue Zeitschrift für Musik 76/50 (5 December, 1879), 514.

48. Paul Cummings, Hans Richter's Conducting Career in England, 1877-1911 (MA Thesis, San Francisco State University 1992), 79.

49. See Hevner Mueller, American Symphony Orchestras.

50. [No author], Goldmark Károly, 33. 
TABle 1 Continued

\begin{tabular}{|c|c|c|c|}
\hline Date & Orchestra & Venue/ City & Conductor \\
\hline $\begin{array}{l}\text { 19/20 February } 1886 \\
1 / 2 \text { February } 1889\end{array}$ & $\begin{array}{l}\text { Boston Symphony } \\
\text { Orchestra }\end{array}$ & $\begin{array}{l}\text { Boston Music Hall. } \\
\text { Boston }\end{array}$ & Wilhelm Gericke ${ }^{51}$ \\
\hline 1 April 1889 & $\begin{array}{l}\text { Boston Symphony } \\
\text { Orchestra }\end{array}$ & $\begin{array}{l}\text { Academy of Music, } \\
\text { Brooklyn }\end{array}$ & Wilhelm Gericke ${ }^{52}$ \\
\hline 5 and 6 March 1886 & $\begin{array}{l}\text { New York Symphony } \\
\text { Orchestra }\end{array}$ & $\begin{array}{l}\text { Metropolitan Opera } \\
\text { House }\end{array}$ & Walter Damrosch ${ }^{53}$ \\
\hline November 1886 & Hallé Orchestra? & $\begin{array}{l}\text { Philharmonic Hall, } \\
\text { Liverpool }\end{array}$ & Charles Hallé54 \\
\hline Winter $1886 / 7$ & Hallé Orchestra & $\begin{array}{l}\text { Free Trade Hall, } \\
\text { Manchester }\end{array}$ & Charles Hallé55 \\
\hline 17 January 1887 & $\begin{array}{l}\text { Hamburg Stadttheater } \\
\text { Orchestra }\end{array}$ & $\begin{array}{l}\text { Hamburg, } \\
\text { Subscription concert }\end{array}$ & Hans von Bülow ${ }^{56}$ \\
\hline 19 January 1905 & Hallé Orchestra & $\begin{array}{l}\text { Hallé concerts, Free } \\
\text { Trade Hall, Manchester }\end{array}$ & Hans Richter ${ }^{57}$ \\
\hline 6 October 1920 & $\begin{array}{l}\text { New Queen's Hall } \\
\text { Orchestra }\end{array}$ & $\begin{array}{l}\text { Queen's Hall, London. } \\
\text { Promenade Concerts }\end{array}$ & Henry Wood ${ }^{58}$ \\
\hline 28 September 1929 & $\begin{array}{l}\text { Henry Wood Symphony } \\
\text { Orchestra }\end{array}$ & $\begin{array}{l}\text { Queen's Hall, London. } \\
\text { Promenade Concerts }\end{array}$ & Henry Wood ${ }^{59}$ \\
\hline
\end{tabular}

\section{Kleist and the Oriental}

The topic of Penthesilea and the Amazons was contentious in Vienna in the 1870s and must have been a subject of debate across the German-speaking world at the time. Although written at the beginning of the century and published in 1810 , Kleist's play had only been read through in manuscript form in the company of his

51. The performance on the Friday afternoon (19 February) would have been a public rehearsal, as was customary with the Boston Symphony Orchestra. Source for Boston Symphony Orchestra concerts: http://archives.bso.org/Search.aspx?searchType=Performance \&Composer=Karl\%20Goldmark (accessed 2 July 2015).

52. Gericke also conducted the Boston Symphony Orchestra in Penthesilea five times during 1902: Symphony Hall Boston (14 and 15 March), Academy of Music, Philadelphia (17 March), Carnegie Hall, New York (19 March), Sanders Theater, Harvard University, Cambridge, MA (10 April).

53. New York Philharmonic Archives: http://archives.nyphil.org/ (accessed 14 April 2015). Walter Damrosch was the son of Leopold Damrosch, who had died in 1883.

54. "Music in Liverpool," Musical Times 27/254 (1 October 1886), 603.

55. "Music in Manchester," Musical Times 27/254 (1 October 1886), 604.

56. See Hans Joachim Hinrichsen, Musikalische Interpretation. Hans von Bülow (Stuttgart: Franz Steiner Verlag, 1999), 496. He appears to have conducted only one performance of Penthesilea. However, this was also the first Goldmark work he ever conducted.

57. Musical Times 46/744 (1 February 1905), 121.

58. BBC Proms Archive. http://www.bbc.co.uk/events/rv36v2/series (accessed 28 April 2015).

59. BBC Proms Archive. http://www.bbcpashto.com/events/erpbj5?work_details=full (accessed 28 April 2015). 
friends during his lifetime. ${ }^{60}$ Coinciding with a rise in interest in Kleist in tandem with a fascination with female hysteria and sexuality, Penthesilea was staged for the first time in Berlin in 1876. ${ }^{61}$ It was an infamous work - the product of a troubled mind, which Goethe had failed to comprehend. ${ }^{62}$ Kleist found in Penthesilea the opportunity to explore his own condition. As he wrote shortly after completion: "It contains my innermost being [...]: all the dirt and, at the same time, the gloriousness [Glanz] of my soul". ${ }^{63}$

In Kleist's hands, the story of Penthesilea and Achilles becomes a vehicle for the exploration of female sexuality, racial conflict, sexual desire and free will in men and the not unrelated issues of madness and rationality. Its examination of the human condition results in highly unpalatable conclusions. There is no triumph of good over evil and the "oriental" in many ways has the upper hand. It was difficult to understand from a psychological point of view, but was fascinating in its wealth of exoticism. In the play there are many examples of the character Penthesilea as an oriental (with the implication "sub-human") being. Kleist examines her with the view of a Westerner looking outwards with curiosity. That is to say, she is clearly depicted as from a different, depraved, but thoroughly organised world of her own, a world with its own cultural boundaries and principles of internal coherence, which is inferior to that of Achilles. ${ }^{64}$ The Amazons are clearly intended to represent "otherness" and the exotic and as such, not all their actions are explained by Kleist - they intentionally remain "other". Penthesilea, however, undergoes a transformation from the point at which Achilles falls for her early on in the play. From her "sub-human" state, she begins to show European reasoning and emotion, although she keeps reverting to the violence that she has always known. But this change comes about too slowly to save her. The tragedy is that she dies stuck between the pragmatic lust of the Amazons and the true love of the Greeks. The oriental aspects of Penthesilea's character are summarised in Table 2.

By the 1870 s the subject, with its eroticism and violence, was viewed by some with distaste. However, it held a fascination for the more modernist in outlook, especially those of the younger generation, such as Hugo Wolf, who composed his own Penthesilea symphonic poem only a few years later. Goldmark, although outwardly a mature man of quiet demeanour, found it inspiring and the overture offered him the chance to appeal to modern tastes.

60. According to Kleist's letters to Marie, there were several read-throughs from the manuscript in the company of his friends in 1807. See Heinrich von Kleist, Dramen. Zweiter Teil, hrsg. von Helmut Sembdner (Munich: Dtv, 1964), 298.

61. Heinrich von Kleist, Penthesilea. Ein Trauerspiel, hrsg. von Hedwig Appelt und Maximilian Nutz (Stuttgart: Reclam, 2001), 128.

62. Kleist, Penthesilea, hrsg. Appelt und Nutz, 127-128.

63. Letter to Marie von Kleist, Autumn 1807. Quoted in Kleist, Dramen. Zweiter Teil, 298.

64. I paraphrase here the analysis of what constituted orientalism in the mid-nineteenth century, according to Edward Said, Orientalism. 25 th Anniversary Edition (New York: Vintage Books, 1994), 40-43. 
TABLE 2 Oriental Characteristics of Penthesilea

\begin{tabular}{|l|l|}
\hline Penthesilea's characteristics & References in the play \\
\hline Her origin in the Scythian Forests & Scene 1. Line 17. Odysseus \\
\hline $\begin{array}{l}\text { Her "dappled tiger" Persian horse with gold and } \\
\text { purple harness }\end{array}$ & Scene 1. Line 225. Antilochus \\
\hline Attired in snake skins & Scene 1. Line 18. Odysseus \\
\hline $\begin{array}{l}\text { Her erotic presence: } \\
\text { - flowing silken locks } \\
\text { - reddened cheeks } \\
\text { - glittering eyes } \\
\text { - thighs astride a horse, riding with furious } \\
\text { passion }\end{array}$ & $\begin{array}{l}\text { Scene 2. Line 290. The Captain } \\
\text { Scene 4. Line 536. Odyseus } \\
\text { Scene 5. Line 721. Prothoe } \\
\text { Scene 3. Line 396. The Aetolian }\end{array}$ \\
\hline Her child-like state & Scene 1. Line 86. Odysseus \\
\hline $\begin{array}{l}\text { Her 'sub-human' dimensions } \\
\text { - a face that cannot be read } \\
\text { - a body resilient to attack }\end{array}$ & $\begin{array}{l}\text { Scene 1. Lines 64-65. Odysseus } \\
\text { Scene 2. Lines 325-330. The Captain }\end{array}$ \\
\hline Irrational behaviour and descent into madness & Scene 22. Lines 2551-2581. \\
\hline Wild mood swings, anger and violence & Scene 20. Lines 2412-2420. Penthesilea \\
\hline Her ability to bewitch through feminine charm & $\begin{array}{l}\text { Scene 14. Lines 1611-1624. Penthesilea and } \\
\text { Achilles }\end{array}$ \\
\hline $\begin{array}{l}\text { Her mutilated body - like all Amazons, } \\
\text { she has had one breast removed }\end{array}$ & Scene 15. Line 1985. Penthesilea \\
\hline $\begin{array}{l}\text { Her association with exotic smells } \\
\text { - roses } \\
\text { - Persian unguents }\end{array}$ & $\begin{array}{l}\text { Scene 14. Line 1718. Prothoe } \\
\text { Scene 14. Line 1651. Penthesilea }\end{array}$ \\
\hline $\begin{array}{l}\text { Amazon customs and ritual, especially the Rose } \\
\text { Festival }\end{array}$ & Scene 15. Lines 1749-2259. Penthesilea \\
\hline $\begin{array}{l}\text { Cruelty - she sets her hounds on Achilles to tear } \\
\text { him to pieces }\end{array}$ & Scene 22. Lines 2595-2598. Amazons \\
\hline
\end{tabular}

Exactly what prompted Goldmark to use this subject, which had, as yet, never been explored in music, is not clear, but it must be connected with his engagement in Viennese intellectual circles. Goldmark recalled in his memoirs that he was searching for an appropriate libretto around the time when he composed Penthesilea and was reading avidly the many texts sent to him by Viennese friends. ${ }^{67}$

65. The scenes quoted here are intended as representative examples. The same themes recur at other points in the play. Line references are taken from the Reclam edition of the text. Kleist, Penthesilea, hrsg. Appelt und Nutz.

66. Kleist did not refer to the most commonly cited sources for the Penthesilea story when writing his play (see Kleist, Dramen. Zweiter Teil, hrsg. Helmut Sembdner, 298) and this characteristic of Amazons was significant in earlier depictions of them as oriental. However, as was known even in Kleist's time, Ancient Greek sources do not bear this out. More recent research too, has confirmed that Amazons did not customarily have one breast removed. See, for instance, scholarship about the Ancient Greek artefacts depicting Penthesilea and Achilles in the British Museum (http://www.britishmuseum.org/explore/highlights/highlight_objects/gr/b/ black-figured_wine_jar.aspx and https://www.britishmuseum.org/explore/online_tours/greece/the_myth_of_ the_trojan_war/achilles_slays_penthesilea.aspx (accessed 25 April 2015).

67. Karl Goldmark, Erinnerungen aus meinem Leben (Vienna: Rikola, 1922), 153. 
Kleist's Penthesilea, which was at last receiving attention in Berlin, is likely to have been one of these. It is telling, however, that Goldmark's Penthesilea was not an opera, but a concert work. It was not a re-telling of Kleist's play, but an outlet for Goldmark's deeply-held feelings. It seems to parallel the position in which Goldmark found himself vis-à-vis the critics, and his quest to prove himself German. ${ }^{68}$ The provocative nature of the subject meant that it was far too risky for Penthesilea to become an opera in 1880s Vienna - this would have to wait until well into the twentieth century.

The first operatic treatment was Othmar Schoeck's Penthesilea, op. 39, also based on Kleist's play, which was premiered at the Staatsoper, Dresden in 1927. Other works on Kleist's Penthesilea include Hugo Wolf's symphonic poem, Penthesilea (1883-1885) and Felix Draeseke's Symphonic Prelude to Penthesilea, op. 50 (1888). ${ }^{69}$ Both Wolf's and Draeseke's works might have been directly inspired by Goldmark's. In Wolf's case, it was a clear case of rivalry, a desire to outdo Goldmark. Whether the same is true of Draeseke is not clear. Draeseke (1835-1913), who was a composition teacher at Dresden Conservatoire from 1884, had been amongst Goldmark's Viennese coffee-house companions in the $1860 \mathrm{~s}^{70}$ and it is plausible that they would have come into contact in later years when Goldmark visited Dresden for rehearsals of his works.

\section{Anselm Feuerbach and Vienna}

The division of opinion about Penthesilea did not only apply to Kleist's play, but also to the paintings of Brahms's friend Anselm Feuerbach, whose Amazonenschlacht was shown at the Vienna Academy in 1874 (see Plate 1 ). ${ }^{71}$ The presence of Feuerbach in Vienna at a time when Goldmark was looking for a subject for a new overture (or possibly an opera) might well have influenced his decision to compose Penthesilea. Feuerbach, who was well established as an artist in Germany, took up a professorship at the Academy of Arts in Vienna in 1874. The Amazons had held a fascination for him from 1857 at the latest, though from the perspective of ancient artefacts, rather than literature. He had already completed one Amazon picture in 1869 and had made studies for others. As he was about to

68. See David Brodbeck, Defining Deutschtum. Political Ideology, German Identity, and Music-Critical Discourse in Vienna (Oxford: Oxford University Press, 2014), 53-69.

69. Karol Szymanowski also wrote a song, Penthesilea, op. 18 (1908), but this sets a text by Stanisław Wyspiański. Goldmark's Penthesilea continued to be a subject of interest in Vienna beyond the 1880s and was amongst a number of scores studied by Alban Berg. See Hofer, Goldmark, 216.

70. See Hofer, Goldmark, 85.

71. Anselm Feuerbach, Amazonenschlacht. Oil on canvas, $405 \times 693 \mathrm{~cm}$. Second version, completed 1873. Now owned by Städtische Gallerie, Nuremberg Inv. No. 476, displayed in the foyer of Nuremberg Opera House. See Jürgen Ecker, Anselm Feuerbach: Entwicklung und Interpretation seiner Gemälde, Ölskizzen und Ölstudien im Spiegel eines kritischen Werkkataloges (Munich: Hirmer, 1991), 330-335. 
take up the position in Vienna, he was anxious about how his work would stand up against the massive, bold and expressive canvasses of Hans Makart, who was leading artistic taste in the city. This was not an easy time for artists in Vienna, whether visual artists, writers or musicians. Some felt that, under the influence of Makart, Vienna was heading for a "fröhliche Apokalypse" [joyful apocalypse] with empty, vacuous art, in which spectacle and the decorative were valued over substance. ${ }^{72}$ Feuerbach's decision to make his debut painting for Vienna a battle of the Amazons was a calculated move, intended to inject fresh energy, passion and substance into a stagnating artistic scene.

PLATE 1 Anselm Feuerbach, Amazonenschlacht, 187373

Reproduced with kind permission of the Germanisches Nationalmuseum, Nuremberg

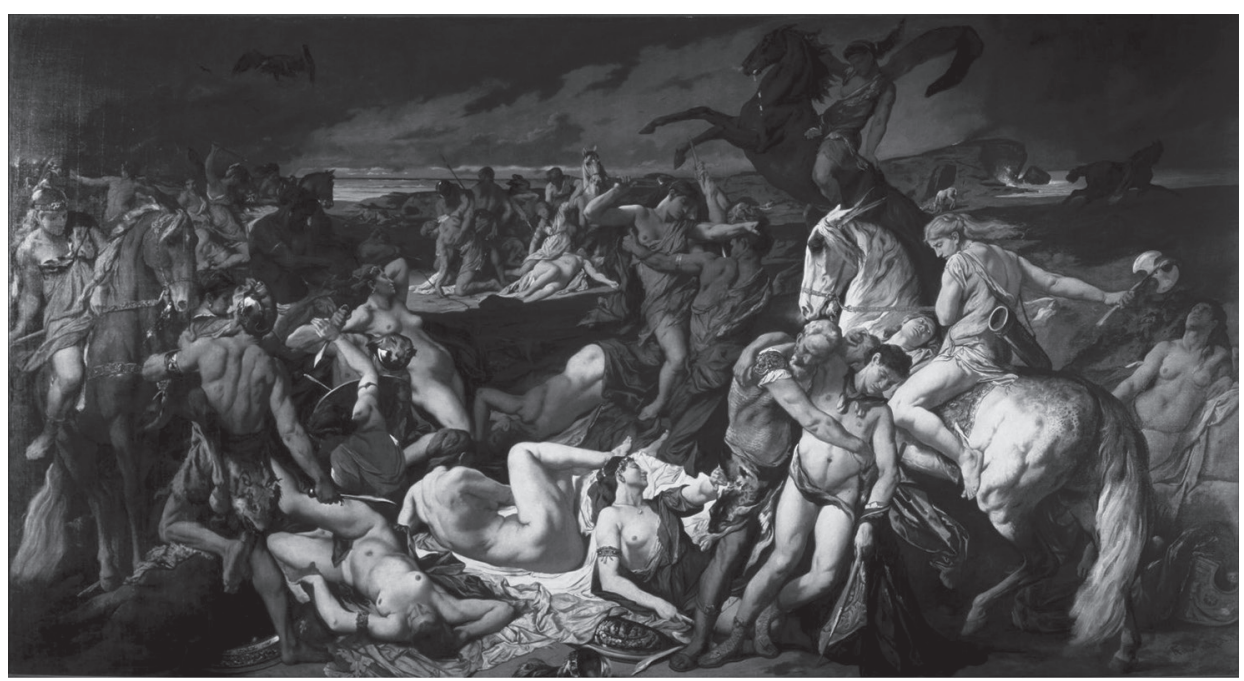

With its stormy atmosphere suggested by stark contrasts between dark and light, its depiction of brutal, yet erotic women, the painting made a great stir in Vienna. The public was generally appalled, but Feuerbach's colleagues remained supportive of him, as did many critics. They saw in it great skill of composition, with many features derived from earlier periods, but also fresh energy and a modern outlook in terms of the subject matter. Apparently Feuerbach understood the ethical content of the picture to be the emancipation of women from the domi-

72. Hermann Broch, "Die fröhliche Apokalypse Wiens um 1880” from Broch's essay "Hofmannsthal und seine Zeit" (published 1955). Reproduced in Gotthart Wunberg (ed.), Die Wiener Moderne. Literatur, Kunst und Musik zwischen 1890 und 1910 (Stuttgart: Reclam, 1981), 86-97. See also Ludwig Hevesi, "Hans Makart und die Secession" (1905) from Acht Jahre Sezession reproduced in Makart. Malerfürst, ed. Renata Kassal-Mikula and Elke Doppler (Vienna: Historisches Museum der Stadt Wien, 2000), 16-17.

73. Source: https://de.wikipedia.org/wiki/Die_Amazonenschlacht (accessed 23 November 2015).

74. See Julius Allgeyer, Anselm Feuerbach (Berlin: Spemann, 1904), 181. 
nance of men. ${ }^{74}$ The focus is thus on the outcome rather than the battle itself. This is not a depiction of a battle actually taking place, but a compilation of individual scenes drawn from great artworks of the past and also from antiquity. ${ }^{75}$

Feuerbach's Amazons display several oriental characteristics, though notably not the obvious use of garish, jarring colours that sometimes signify the oriental. ${ }^{76}$ Their jewellery is perhaps the most evident feature: they have gold armbands set with lapis lazuli, helmets with peacock feathers. Their poses also mark them out as oriental: their detached facial expressions, flowing locks (though note that these women are European fair-skinned types), unguarded erotic poses (reclining, as would be used later in Vienna by Klimt, for example in Fish Blood) and sitting with thighs astride horses with golden harnesses, all suggest emancipated women. Apart from the exotic silky drapes of various hues, there is none of the sensuousness of Kleist's Penthesilea. The absence of flowers or foliage ensure a focus on the brutality of the slaughter: a de-feminising of the Amazons, ${ }^{77}$ as in the final scene of Penthesilea.

Goldmark surely would have seen the painting and read the criticism, possibly in the company of Brahms, with whom he was in close and frequent contact at the time. ${ }^{78}$ It seems likely that he would even have met Feuerbach. Although Brahms admired Feuerbach's work and there had been mutual influence between the painter and the composer, he could not comprehend the Amazonenschlacht and it would certainly have been a talking point in his circle of friends. ${ }^{79}$ Beyond the Amazonenschlacht of 1873, Feuerbach was at work on further Amazon pictures and clearly this work did not represent his final thoughts on the subject. ${ }^{80}$ This suggests that the Amazons were still a topic of conversation in Vienna even after the appearance of the Amazonenschlacht at the Academy in 1874. What is more, Feuerbach's inspiration stemmed from his visits to Italy in the 1870s, where he had made numerous studies for the Amazonenschlacht. Goldmark and Brahms had only recently visited Italy when Goldmark began work on Penthesilea. One can only speculate about what Goldmark's reaction might have been to

75. See "Manuela Annibali, Feuerbach und die Antike," Anselm Feuerbach (Ostfildern-Ruit: Hatje Cantz, 2002), 64-67. Also Ecker, Feuerbach, 334.

76. In 1870s Vienna Emile Ranzoni frequently criticised Feuerbach for his dull palette, which mostly ranged from browns, to greys and subtle shades of blue, green and pink, though apparently this was not a particular issue for him with the Amazonenschlacht. See Ecker, Feuerbach, 332.

77. Nature, in particular flowers are generally considered to represent the feminine in literature. See, for example, explorations of Goethe's poem Ganymede in Lawrence Kramer, Music as Cultural Practice 1800-1900 (Berkeley: University of California Press, 1990), 168.

78. He appears to have given Brahms a copy of the score of Penthesilea in which he wrote a personal dedication. This is now in Mainz at the Wissenschaftliche Stadtbibliothek. See http://www.brahms-institut.de/ web/bihl_digital/widmungswerke_units/GoldmarkC_op_031.html (accessed 28 April 2015).

79. Letter quoted in Natasha Loges, "Exoticism, Artifice and the Supernatural in the Brahmsian Lied," Nineteenth-century Music Review 3 (2006), 165-166. Loges also discusses in detail Brahms's deep appreciation of Feuerbach's works.

80. Feuerbach completed an oil study for Amazonen auf Wolfsjagd in 1874, for example. See Ecker, Feuerbach, 339. Following its presentation in Vienna in 1874, the 1873 Amazonenschlacht was shown again in Munich in 1876, Berlin in 1880 and 1905, thus remaining in circulation through the time when Goldmark's overture was in preparation and being premiered. Ecker, Feuerbach, 334. 
the Amazonenschlacht, but certainly Feuerbach's work and Goldmark's overture have something in common, reflecting a late rather than an early (Kleistian) nineteenth-century approach to the oriental subject. Feuerbach did not reproduce or imitate ancient sources, but "reawakened" their emotional states for the present day. ${ }^{81}$ It was the means he discovered to speak with an individual voice and express his own sentiments. Similarly, Goldmark did not seek to imitate the world of Penthesilea by including local colour through "oriental" melodies or instruments, as he had done in The Queen of Sheba. Working on an overture for modest orchestral forces ${ }^{82}$ Goldmark had no recourse to the technical devices or signifiers available through opera, such as exotic scoring, especially the use of extra percussion, the possibilities of vocal expression or the insertion of exotic dance tableaux. ${ }^{83}$ Instead he extended conventional compositional techniques, particularly in terms of harmony and form, to explore the play's emotional content and the conflict between occident and orient. Orientalism here is concerned much more with an individual and extreme form of expression and control of the work's structure. It is built into the fabric of the music through contrasts in phrasing, rhythmic patterning, articulation and harmony. An examination of how Goldmark creates drama in the work reveals how this operates.

\section{Drama in the music of Penthesilea}

Although Penthesilea runs as one continuous movement, Goldmark supplied subtitles to assist the audience's comprehension: Penthesilea and Achilles; The Rose Festival; Battle and Death. These are a simple guide to the action in the play and connect the music directly with Kleist, distinguishing the work from a more generalised depiction of the Amazons of the Feuerbach type. Goldmark does not give a full account of the story as a preface to the score as he provided for the Sakuntala Overture. Although a detailed account was sometimes included in concert programmes, as one programme note-writer put in, "its musical divisions are outlined boldly enough to set in motion the hearer's imagination" ${ }^{84}$ Although the play often refers to sounds, such as horn calls, thunder and the singing of the Amazon women, Goldmark does not compose these into the music. Instead, he gives impressions of the action, conveying the feeling rather than depicting specific events.

As Goldmark's three headings suggest, the overture has the extended sonata form conventional for the concert overture, as distinct from the symphonic poem

81. Manuela Annibali, "Feuerbach und die Antike," 67.

82. It is scored for strings, 2 flutes and piccolo, 2 oboes, 2 clarinets in B flat, 2 bassoons, 2 trumpets, 3 trombones, tuba and 2 timpani. This is similar to contemporary symphonic scoring by Brahms.

83. Some of these are discussed in Derek B. Scott, "Orientalism and Musical Style," Musical Quarterly 82 (1998), 309-335.

84. Concert Programme Boston, 2 February 1889. No author named, but possibly by G. H. Wilson. 
at this period. Note, however, that the central section is not a development in the classical sense. The three main sections roughly correspond to the dramatic action, although Goldmark does not indicate in the score where each of his three scenes begins.

TABLE 3 Form and bar numbers aligned with Goldmark's headings

\begin{tabular}{|l|l|l|l|}
\hline Heading & Bars & Tempo & Formal section \\
\hline Penthesilea and Achilles & $1-253$ & Allegro energico & "Exposition" \\
\hline The Rose Festival & $254-420$ & Andante ma non troppo & "Central Section" \\
\hline Battle & $421-622$ & {$[$ con brio $]$} & "Recapitulation" \\
\hline Death & $623-681$ & Andante maestoso & "Coda" \\
\hline
\end{tabular}

\section{a) Penthesilea and Achilles}

In the opening section, 'Penthesilea and Achilles', the music can be divided into two contrasting thematic groups, the first representing Penthesilea and the Amazons and the second representing Achilles. The first few scenes of Kleist's play explore the background to the conflict and battle strategies as the Greeks discuss whether to use the Amazons as allies in their quest to conquer Troy. We learn of the ferocity and also the eroticism of the Amazons. They surround the Greeks and take prisoners, but there is relatively little combat at this point. With Goldmark there is no preamble, no observation of the Amazons from afar. He uses an easily identifiable dotted figure and unconventional harmony to represent Penthesilea, entering with brute force, stirring up clouds of dust, as shown in Example 1. She is rough, dirty and merciless. These are the chords that struck Hanslick and Billroth so forcefully in the piano duet arrangement.

The sense of force and the "oriental" depraved nature of the Amazons is created by the unconventional harmony of bars $1-2$. The timpani suggest a movement from I to $\mathrm{V}$ in $\mathrm{G}$. The string parts, however, conflict with this, moving from chord IV with an added sixth to Ic with an added sixth. The following two bars are reassuringly more conventional: Ib-IV-V7-I. This harmony was clearly ground-breaking at the time and problematic to explain along traditional lines. The passage was quoted and discussed at length by Hadow in 1901. It was cited as an example of the "recent" development of the capacity of one note to perform the same function harmonically as another. In this example he sees the A in the first chord to be equivalent to G. Although, being bound by tradition, Hadow cannot quite express it this way, essentially what he recognises is that pitches that do not belong to a chord are not performing a traditional harmonic function, but are there to colour the sound quality of the chord. This technique pervades throughout the overture. ${ }^{85}$

85. W. H. Hadow, "Suggestions towards a Theory of Harmonic Equivalents," Sammelbände der Internationalen Musikgesellschaft 2/3 (May, 1901), 470-480 and 484. 
EXAMPLE 1 Opening theme, bb. 1-4 (Extract from full orchestra)

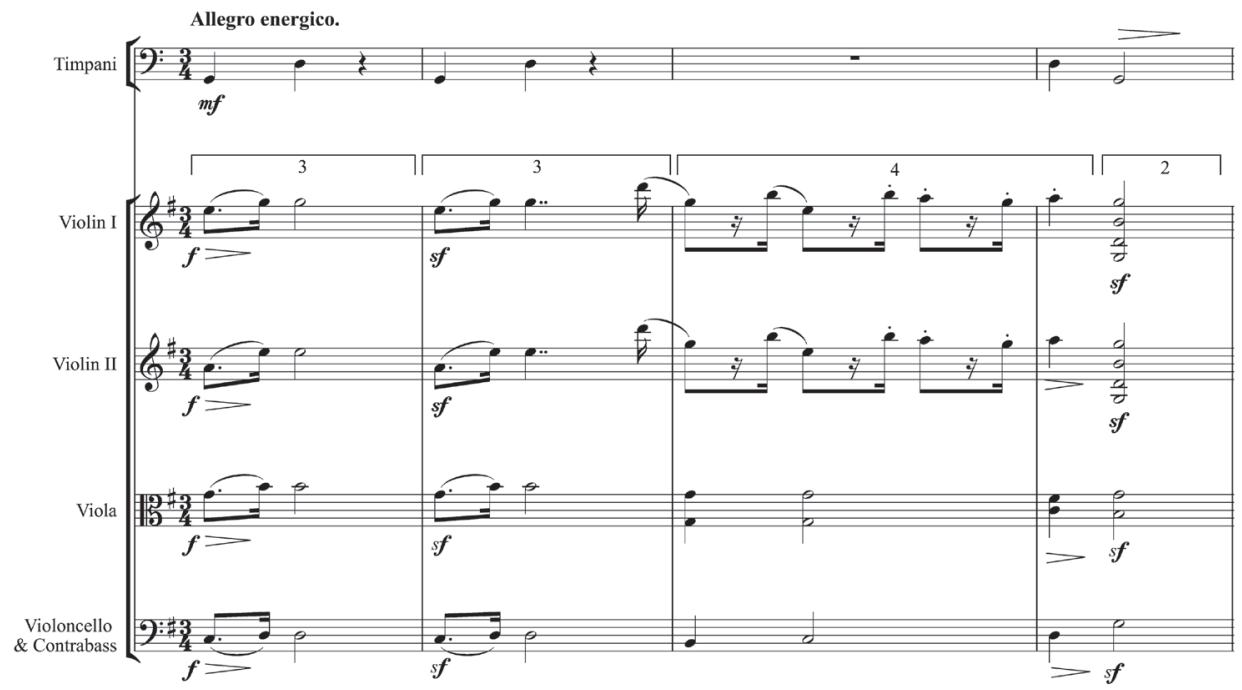

The martial character of this four-bar closed theme associates itself in our minds with Penthesilea, appearing with her actions within the story and serving also to cement our view of her as an object of desire. However, the harmonisation, the homophonically-set iambic figures and the cross-metrical structure are unsettling. There is a sense of two bars in $3 / 4$, followed by one in $4 / 4$ and completed with one in $2 / 4$.

The theme undergoes immediate development when it is repeated, expanding on the first impression of the character of Penthesilea. As it becomes more regular metrically and triplet quavers are introduced, Goldmark is possibly alluding to her riding a horse, a concept regarded by some as an oriental gesture. ${ }^{86}$ More significant still, are the building dynamics, accents, the full orchestral setting, wide leaps in the melody, repetition and rising movement by step to suggest violence and mounting tension. Note also the "oriental" touch created by the A\# (essentially the raised second degree of the $\mathrm{G}$ major scale), which is emphasised several times in this passage as part of the augmented dominant triad. Such harmony was considered to be a means to introduce oriental character at the time, ${ }^{87}$ though it here performs a decorative function and is not introduced in the context of a modified $\mathrm{G}$ major scale (Example 2). $278-284$.

87. See Scott, “Orientalism," 312-313. 
EXAMPLE 2 bb. 13-22
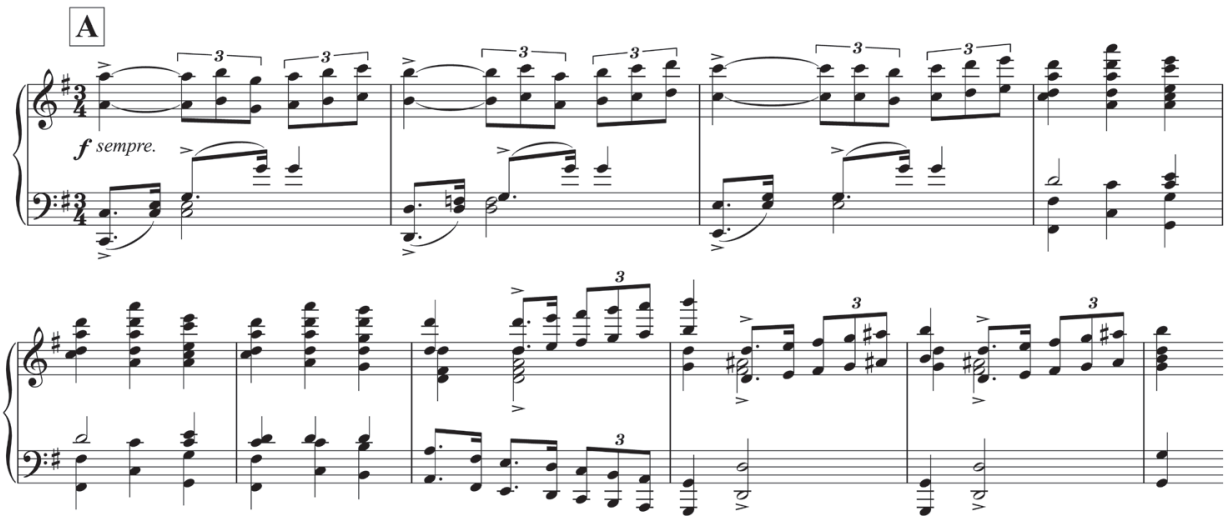

Further development of the theme illustrates that Penthesilea is not a lone figure, but is leading her troop of Amazons. This is shown firstly with points of imitation, creating antiphonal effects across the orchestra, and then through metrical complexity. Here the metrical ambiguity suggested in the opening phrase becomes the salient feature of the music as the winds are essentially in $3 / 2$, but not synchronised with the strings in 2/4 (Example 3).

EXAMPLE 3 bb. $58-63$

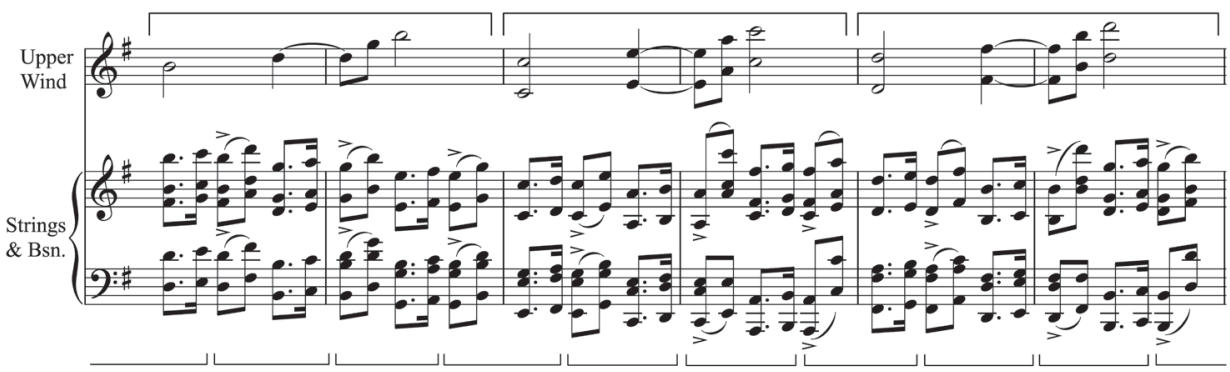

Prolonged harmony and a rising chromatic scale continue this intensification of the scene, especially when combined with hemiolas and syncopation.

We do not meet Achilles face on as we did Penthesilea. Instead we first gain a slightly obscured view of him as Goldmark introduces new textural material rather than an actual theme. This reflects the way in which Kleist describes Penthesilea's first view of Achilles. His character is plain, represented by soft, legato, flowing music (Example 4). 


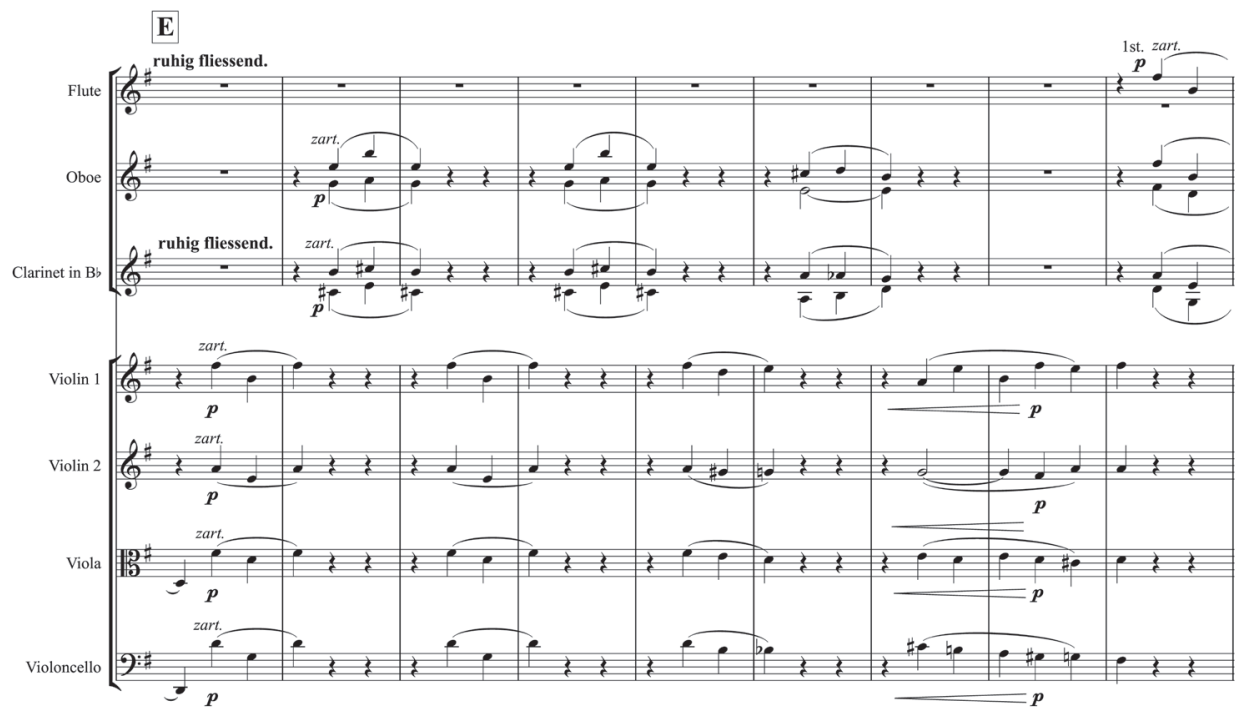

The use of the interval of a fifth in these off-beat rocking figures of alternating notes shared between groups of instruments relates the music back to the previous section, where leaps of a fifth are a strong feature. However, this eight-bar phrase seems reassuring after the Amazon music, especially given its avoidance of stress on the first beat of the bar, and with its movement from B minor to D major.

It is not until Achilles begins to approach Penthesilea that we learn much about his nature. This is suggested by the development of the pattern (Example 5) into a cantabile melody on the clarinet. With its steady, pizzicato bass line, it has a waltz-like, romantic character.

EXAMPLE 5 bb. 123-131

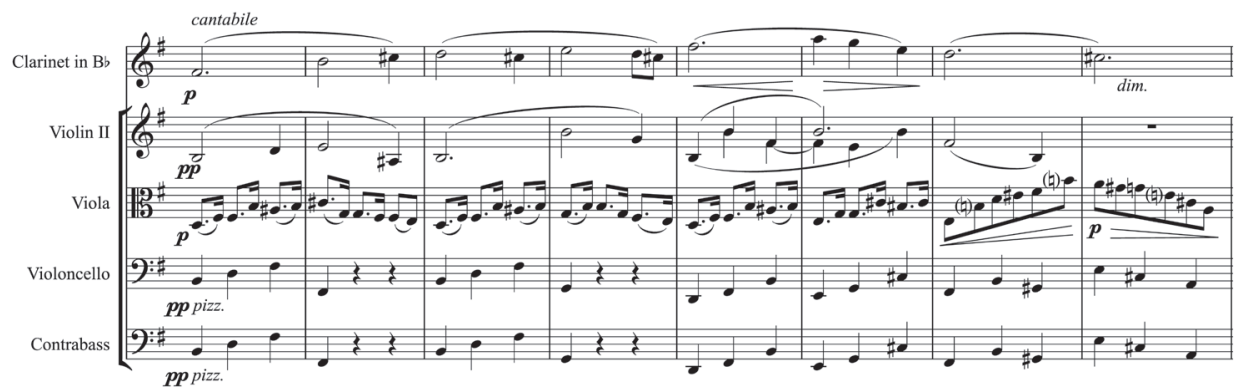


Notably, however, Penthesilea is almost always somewhere in the background, suggested by the presence of her dotted quaver rhythm in accompaniment figures. After this the legato, rocking figure shown in Example 4 eventually becomes powerful, manly and triumphant when set for full orchestra playing $f f$, a highly appropriate development to represent Penthesilea admiring Achilles.

In the play the Greeks decide they should not engage with the Amazons, but Achilles has fallen under Penthesilea's spell and will not leave. Meanwhile, the Amazons prepare to hold their fertility ritual, a Rose Festival, with their Greek prisoners, but it does not take place. Penthesilea's lustful ravings, which are on the cusp of madness, have led to confusion: some of the Amazons think she ordered the Rose Festival, but actually she is simply intent on capturing Achilles. She is in a state of hysteria, quite distinct from the calculated moral code of procreation of the Amazons. At this point the play describes Penthesilea's emotions: her feelings of lust, her delirium and dreams, her madness and inability to reason. Her companion Prothoe attempts to persuade her against seducing Achilles, but she insists it is her destiny. The Amazons then attack the Greeks and Penthesilea is mortally wounded by Achilles. As she is dying, Achilles falls in love with her. She will regain some strength before her final decline and the scene is set for the act of love between Achilles and Penthesilea at the Rose Festival. Goldmark does not seem to represent this complex part of the play directly, although all the emotions it contains have been presented in the exposition. The music now undergoes a transition into the Andante ma non troppo Rose Festival.

\section{b) The Rose Festival}

The central Rose Festival section of the overture does not develop earlier themes until it approaches the recapitulation. Instead it has a character all its own, introducing new themes and textures, and thus functioning almost like an independent middle movement. ${ }^{88}$ This section is in E major with a much more focused tonal centre than any music so far. This is appropriate to the stasis in Kleist's play and, reflecting a change in the action, offers a contrast with the opening $\mathrm{G}$ major and dark B minor sonorities. Goldmark leads us to it logically in a long transitional passage around a pedal note B (fifth degree of the E major scale) from bar 234 onward, which has a dark, mysterious feel created by its low registral tessitura. The transition contains an oriental reference at the end: a scale in the solo clarinet with a long chromatic appoggiatura on A sharp. This is the same pitch that was used to give Penthesilea oriental character in the exposition. Here, however, it is not part of a distinctly oriental scale. It could be conceived as the raised fourth degree in $\mathrm{E}$, but the diatonic fourth degree is also present, reducing the "oriental" effect (Example 6).

88. A similar technique is used by Liszt in his Piano Sonata in B minor. See Ratner, Romantic Music, 292. 
EXAMPLE 6 bb. $243-253$

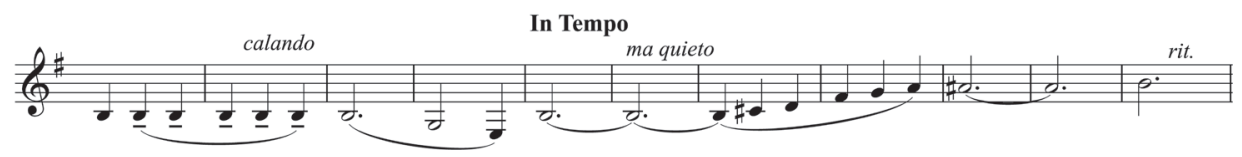

At the Andante ma non troppo the music becomes lyrical with a romantic sweetness. There are some faint oriental touches too. Firstly, the use of the oboe and the inclusion of semiquaver decorations and a trill. The oboe's sonority is less "oriental" than the mystery-laden deep tone of a cor anglais would be, but nevertheless more exotic than the flute or violin that follow. Secondly, the drone accompaniment in fifths in the cello and double bass and the syncopated figure in the upper string parts evoke folk music (Example 7). Goldmark had used a similar texture to accompany the main theme in Sakuntala, ${ }^{89}$ but unless the listener is seeking to understand the music in this context, these compositional devices might easily be passed over. They were used frequently in the nineteenth century, finding their way into music evoking folk culture, especially Dvorak's orchestral works, whose Slavonic Dances were being premiered across Europe around this time. ${ }^{90}$

EXAMPLE 7 bb. $254-262$

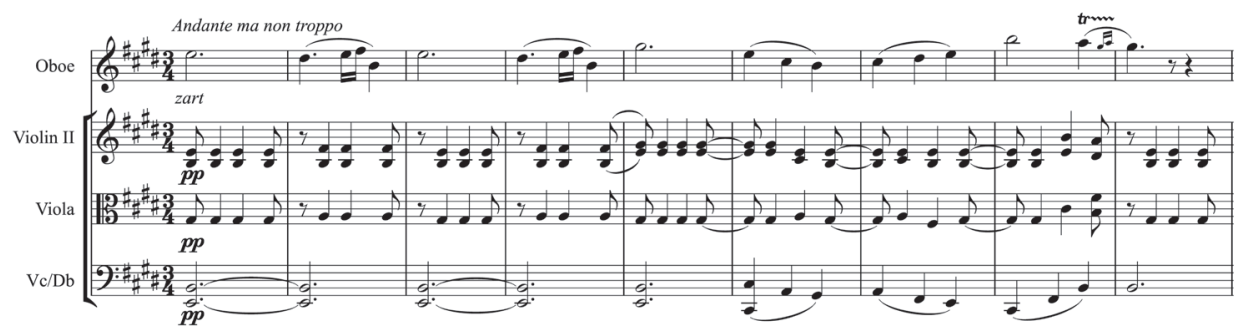

The dreamy, sensuous music of the Rose Festival, and particularly its development, seem to correspond with the action in the play. Key features are the varied orchestration and flowing quaver accompaniment, the ebb and flow of passion through swelling and falling dynamics and registral changes, the doubling of octaves to thicken the texture at the height of passion, and the emergence of a luscious counter-melody in the viola and cello. The complexity of the harmonic structure as Goldmark leads us through remote keys and enharmonic changes enhances further the impression of feelings of love and desire.

89. See Hofer, Goldmark, 109-110.

90. The "oriental" was sometimes considered to encompass European folk culture (as distinct from European art music) as well as the non-European in music. See Loges, "Exoticism," 145. Thus exactly what audiences perceived as "oriental" or "exotic" in Goldmark's music is impossible to define with any certainty. 
As Achilles approaches Penthesilea disarmed, their love is declared and sensuously she adorns him with roses. Comparing this passage (Example 8) with an example from Kleist's text illustrates how closely Goldmark reflects the emotional content (Kleist, Penthesilea. Scene 15, lines 1174-1185):

\section{ACHILLES}

Who are you, wondrous woman?

\section{PENTHESILEA}

No, come here - Be still, I say, and soon you will find out.

- Only a garland of roses here

Over your head, and one about your neck,

Down to your arms, your hands, your feet, about

And up - your head again - and it is done.

- You breathe so deep?

\section{ACHILLES}

Fragrance of your sweet lips.

\section{PENTHESILEA}

It is the roses strewing forth their scent. What more?

\section{ACHILLES}

But I would try them where they grow.

\section{PENTHESILEA}

When they are ripe, my love, then you shall pluck them. Now it is done.

- O look, I beg of you, see,

How roses with their melting glow become him!

How gleams his face like thunder dark among them! ${ }^{91}$

In the play this is not straightforward passion leading to the act of love, but explores the mixture of emotions: love, lust, denial, sexual gratification and the need to procreate. It turns into a complete history of the Amazons in which Kleist proffers a sympathetic view of these uncouth warrior women. Similarly, Goldmark's music does not depict a pure and undisturbed love-scene. Just as the passion builds, the lyrical music is truncated abruptly (bar 319), then begins again with detailed fluctuations of tempo. Further new material is then introduced, based on the lyrical theme, but with hints of Penthesilea's dotted rhythm. The shimmering

91. English translation from F. J. Lamport, Five German Tragedies (Harmondsworth: Penguin Books, 1969), 379 

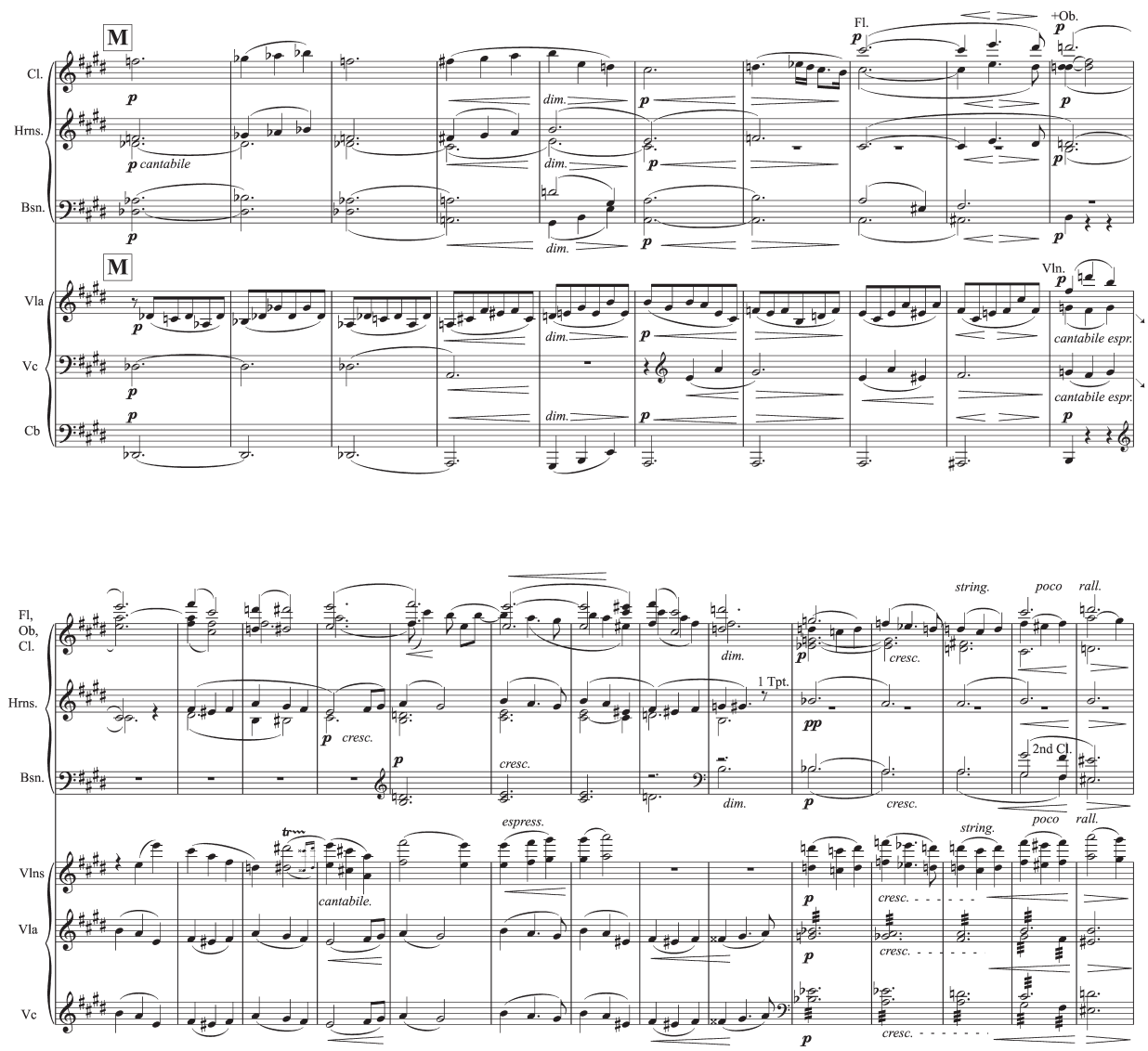

tremolo string accompaniment (bars 320-323) is further hint at romantic textures used frequently by other composers and is particularly effective because it is only heard twice in the overture. ${ }^{92}$

The Rose Festival concludes at bar 384 as another long transition begins, this time leading to the Recapitulation. Little by little the violence of the opening of the overture is reintroduced. Tension is built in the music by moving up from a low, winding chromatic line in the bassoon and clarinet treated sequentially and punctuated with increasingly aggressive string chords (Example 9).

92. The second occurrence is within the funeral march for Penthesilea almost at the end of the work, bb. 658-668, as an accompaniment to a reflective cantabile melody in the clarinet. 
EXAMPLE 9 bb. 381-394

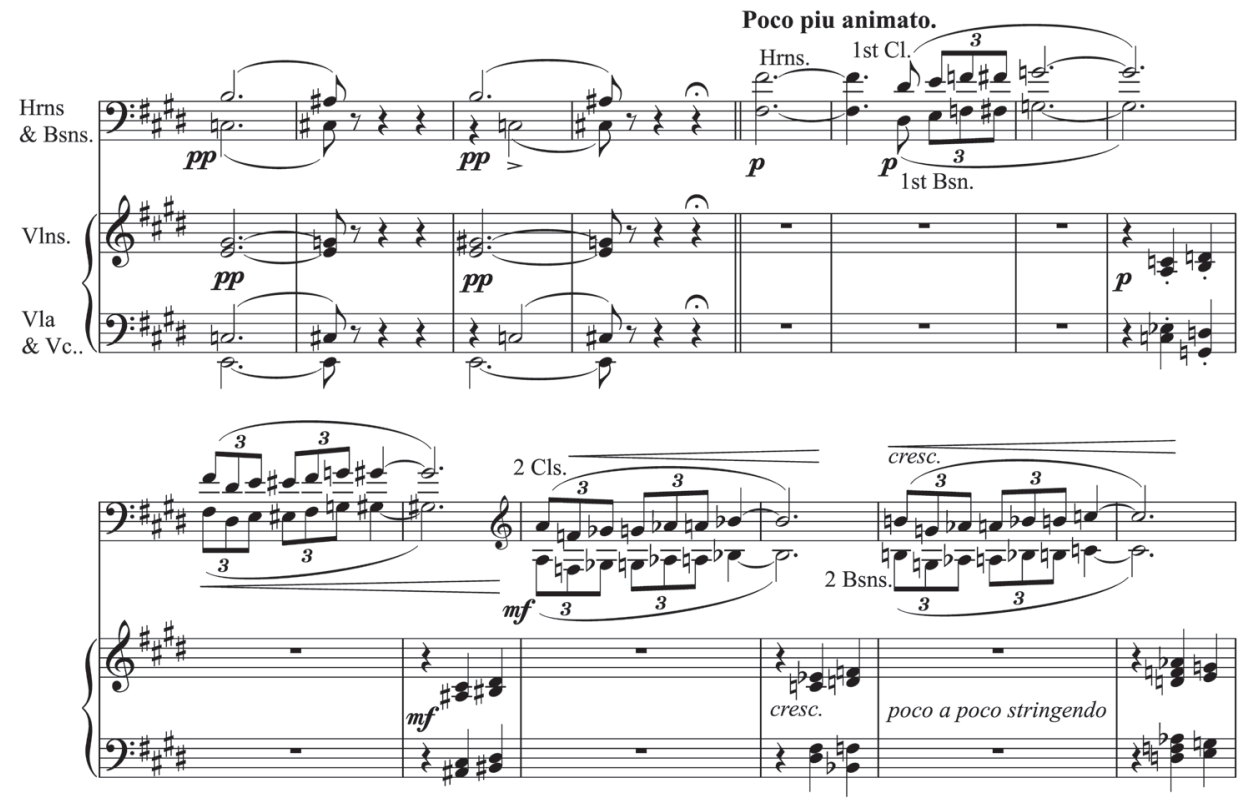

A much more explicit erotic reading of the Rose Festival than I have given here is conceivable. Given his knowledge and appreciation of Wagner's music, it does not seem too far-fetched to suggest that there might be parallels with the Venusberg music from Tannhäuser. ${ }^{3}$ Phrase structure, melodic shape, articulation, and climax-building could all be analysed to explain how Goldmark achieves sensuousness in music. Similar to a matching of operatic text with specific musical ideas, features might be pinpointed that could depict key events, images or lines from Kleist's play. In all probability some contemporary listeners did indeed create their own fantasies around what they heard, as they did even with Brahms's absolute music. ${ }^{94}$ However, as far as is known, Goldmark did not speak of these aspects of Penthesilea, if indeed they are to be understood in this way. He certainly never supplied an explicit programme as did Wagner for concert adaptations of his works. ${ }^{95}$ Considering the company Goldmark generally kept around this time, which roughly equated to the circle of friends around Brahms, possibly, as Clara Schumann felt about Wagner's music, ${ }^{96}$ it was beyond the limits of decency for him.

93. See Laurence Dreyfus's discussion of the Venusberg music from Tannhäuser in Wagner and the Erotic Impulse (Cambridge, MA: Harvard, 2017), 84-92 and 226-227.

94. See Ratner, Romantic Music, 5. Ratner draws on the letters of Elisabeth von Herzogenberg to Brahms. The Herzogenbergs also knew Goldmark and Elisabeth mentions hearing Goldmark's Rustic Wedding Symphony in her correspondence with Brahms. See Kalbeck (ed.), Brahms. The Herzogenberg Correspondence, 59.

95. See Dreyfus, Wagner, 84.

96. See Dreyfus, Wagner, 84. 
The transition from the Rose Festival into the Battle and Death section is rather like an awakening to reality by Penthesilea. According to Kleist, she realises that she is about to succumb to Achilles, rather than he to her, and a violent rage boils up inside her. This irrational behaviour offers an oriental climax and the music does not disappoint. Finally, anticipating the actual Recapitulation, a fragment of the furious Penthesilea theme bursts in at bar 410 "con brio," underpinned by heavy triplet quavers and drum rolls. These gestures are all the more effective because Goldmark uses them sparingly (Example 10). ${ }^{97}$
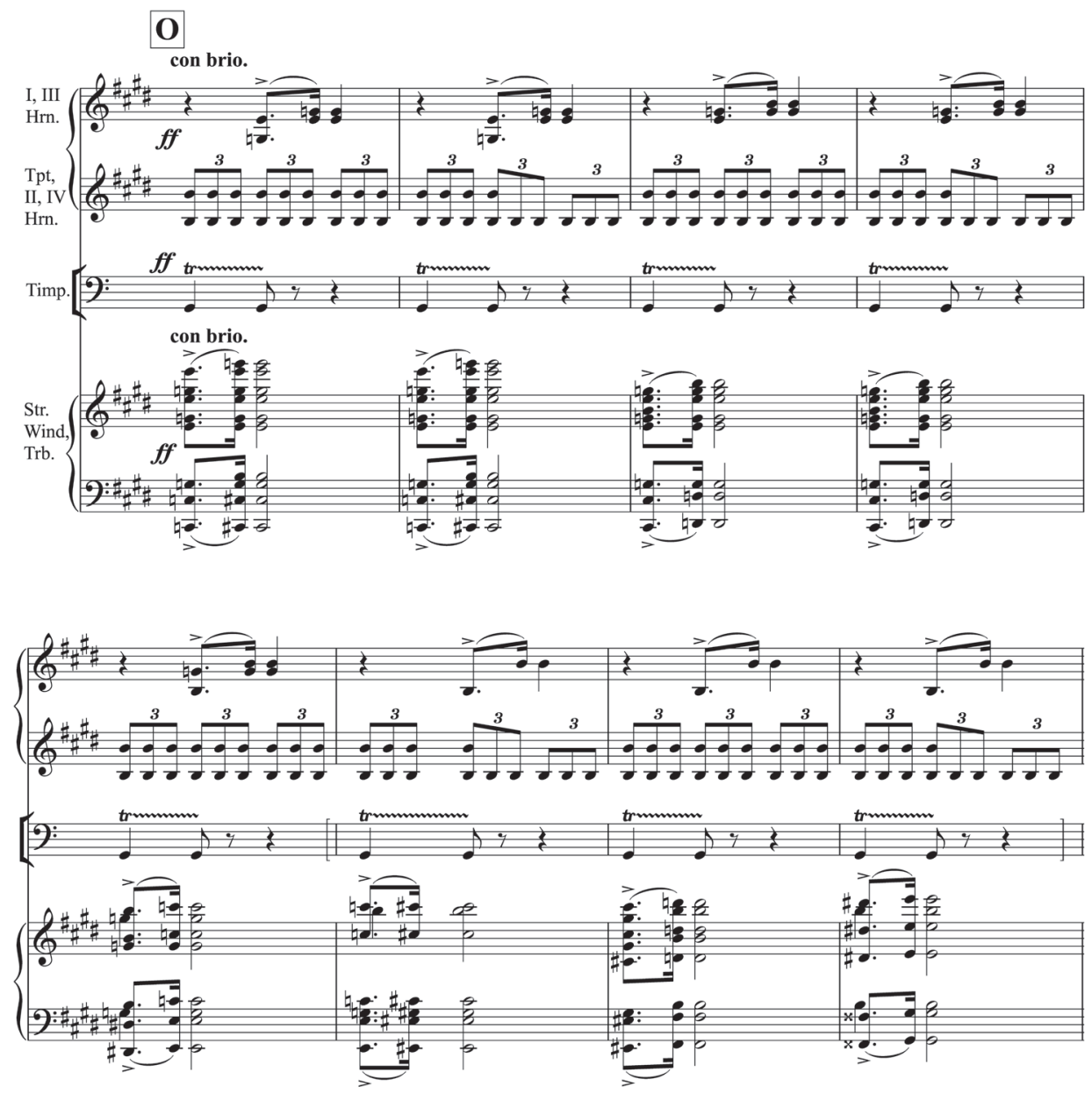

97. The last three bars of the timpani part appear in brackets as they are not present in the score printed by Schott. See Carl Goldmark, Ouverture zu Penthesilea (Mainz: Schott, 1879), 51. 


\section{c) Battle}

The play concludes with a short series of action scenes with the most violent and bloody assault imaginable on Achilles by Penthesilea and a pack of hounds. In the overture, this corresponds with the Recapitulation, and all the main thematic material connected with Penthesilea and Achilles returns. It seems intensified, and there is one new galloping theme marked poco animato, which replaces some of the gentler material from the exposition (Example 11). This phrase recalls the Storm March of Beethoven's Wellington's Victory op. 91 (1813), when it is repeated up a semitone, although Goldmark does not overwork the gesture as Beethoven does in his strictly programmatic work.

EXAMPLE 11 bb. 477-484

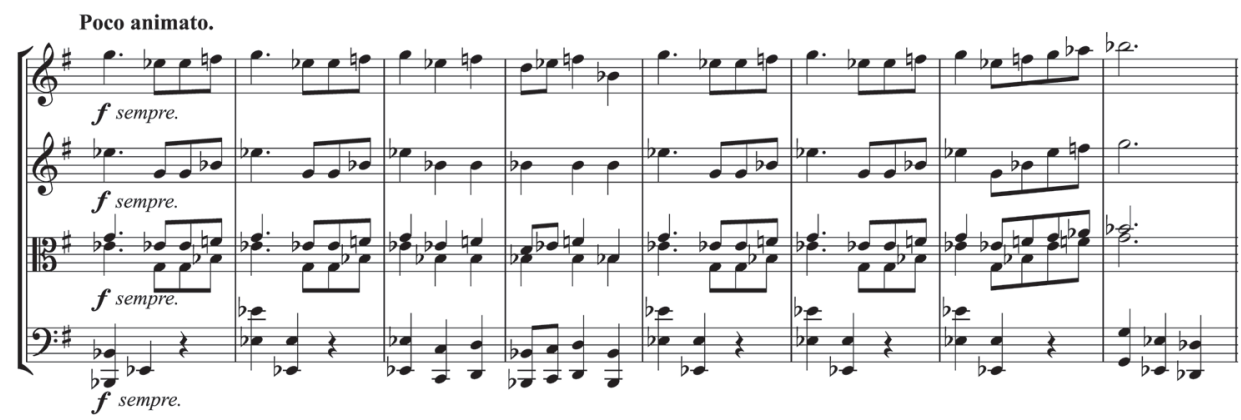

The transition towards the coda marks the height of the battle and the onslaught of Penthesilea's hounds, with increasing tempo through a chromatic ascent using a new development of the Penthesilea thematic material (Example 12).

Goldmark works the music to a standstill through processes of liquidation. The music fragments and maximum tempo, dynamics and orchestration are reached at bar 622, clearly depicting the point of the death of Achilles in the play.

\section{d) Death}

The Coda of the overture is an unexpectedly prolonged affair, representing the remorse of Penthesilea and her inevitable death (Example 13). Her death is indicated by a passage of extremes in which violent chords in the winds alternate with muted pianissimo strings (bb. 623-628). The most oriental of music in the entire overture follows - could this be Penthesilea's dying breaths (bb. 629-633)? 
EXAmPLe 12 bb. $580-587$
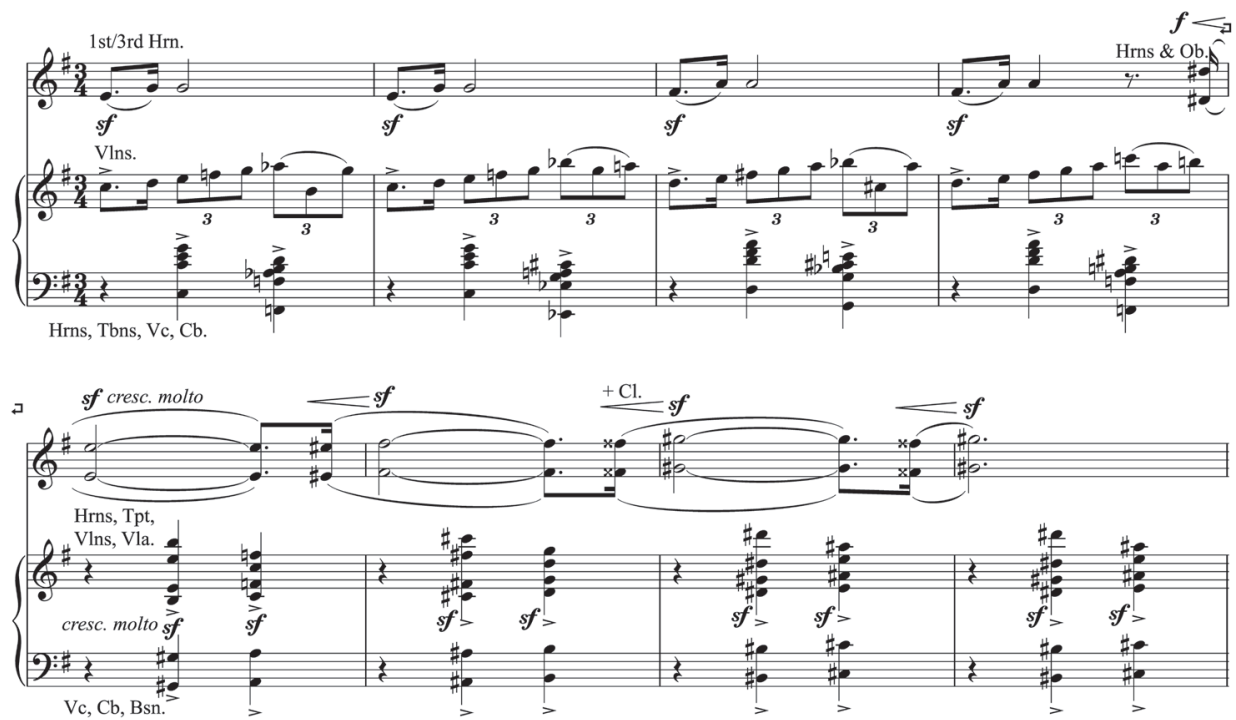

ExAmPLe 13 bb. 623-633
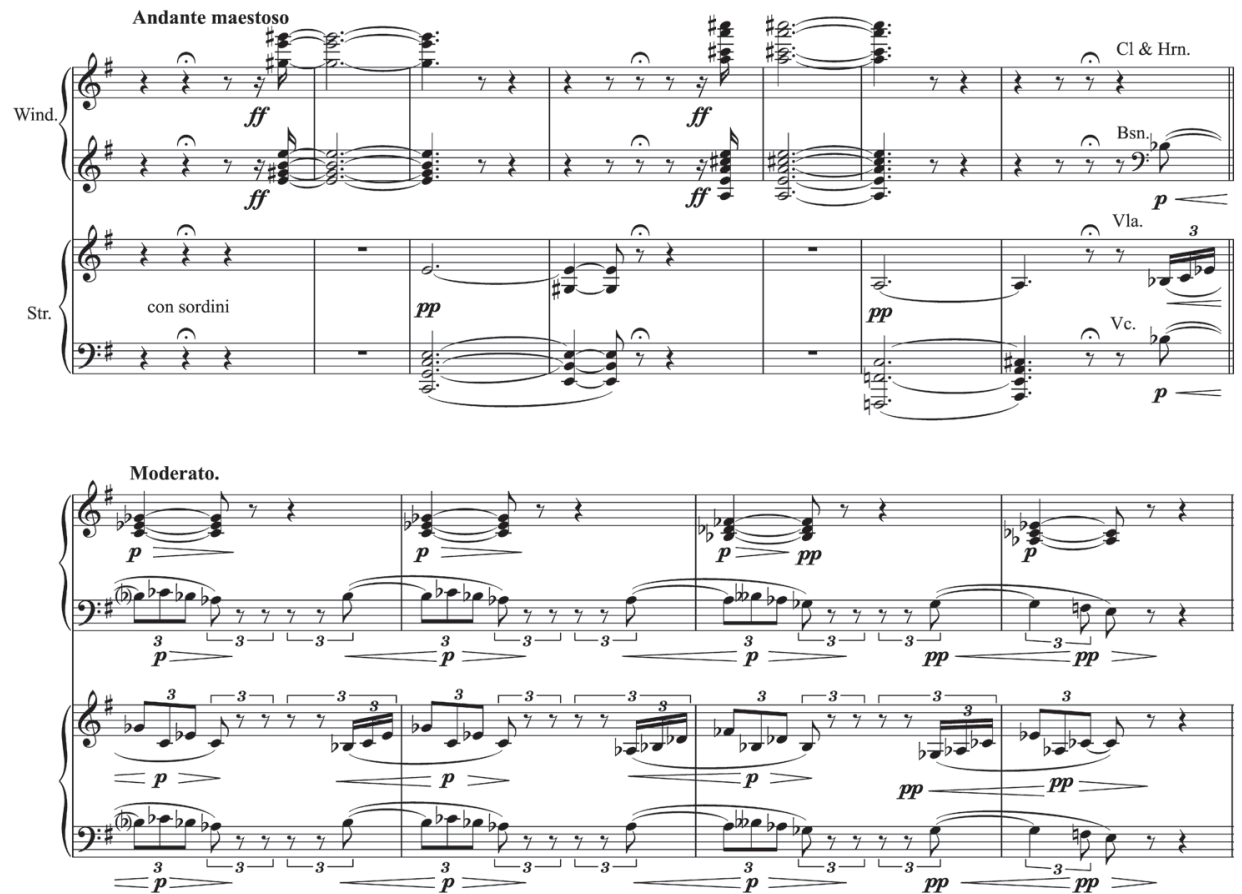
The overture concludes with a funeral march in E minor (Example 14). There is a passing resemblance here, as in other places in the Penthesilea music, to the Witches Sabbath in Berlioz's Symphonie Fantastique, particularly the chromatic triplet descent at bars 640-641.

EXAMPLE 14 Andante ma non troppo, bb. 636-643
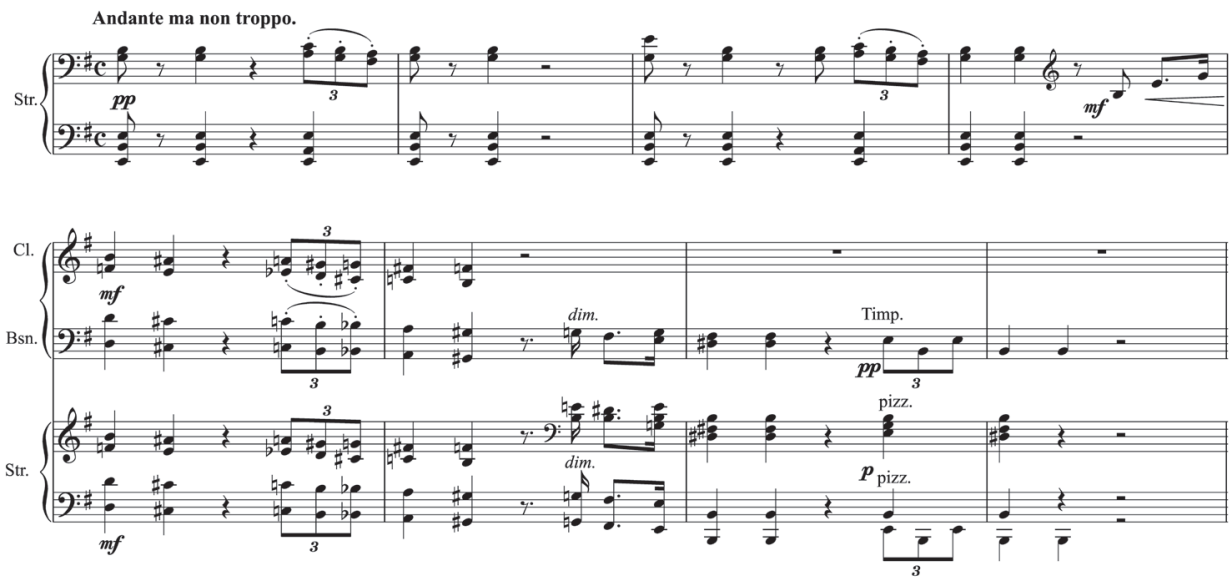

\section{Conclusion}

Having examined Goldmark's Penthesilea in some detail, it is clear how complex and carefully crafted his music is and how he makes full use of late romantic compositional techniques to convey the spirit of Kleist's play. The work can be closely connected with the drama, yet it describes emotional states and their fluctuations much more vividly than the action itself.

Goldmark achieved success with Penthesilea, especially in America and England, but this was not a work that helped the public to understand him, for some appearing too extreme in subject and expression. The title of the work, if not the music itself, contributed to the widely-held view that he was intent on representing the oriental at the expense of "melodic invention and thematic development," musical equivalent of Makart. ${ }^{99}$ Goldmark made no attempt to defend himself, at least in print, and it was largely owing to Hans Richter that Penthesilea continued to be performed. It should be noted that Penthesilea was composed at a busy time in Goldmark's life and that it was overshadowed not only by his own recent works, but also by the popularity of other new music that would have a more

98. Emil Naumann's Illustrierte Musikgeschichte (1890). This English translation from Ernest Newman, Modern Music (New York: National Society of Music, 1915), 242.

99. Eugen Schmitz's revised edition of Emil Naumann's Illustrierte Musikgeschichte (1890) contains a representative example. English translation in Newman, Modern Music, 242. 
enduring place in concert repertoire, such as Brahms's Tragic Overture. Nevertheless, it compared favourably with the Penthesilea works of his contemporaries Hugo Wolf and Felix Draeseke, both of whom felt the need to call on much larger orchestral forces and compose with far less economy of means. In both cases the result was an apparently long and drawn out musical version of the story, much less able to captivate listeners than Goldmark's.

Ultimately it is Goldmark's approach to the oriental that makes this a particularly interesting work. As I have shown, the orientalism of the play is conveyed most strikingly through violent music, stark contrasts and sensuous, romantic writing. Penthesilea has clear parallels with Feuerbach's Amazonenschlacht, especially in its reinterpretation of a classical subject in the light of the philosophical and psychological concerns of the 1870s. Feuerbach and Goldmark both offer considered readings with reference to earlier techniques and specific works. In Feuerbach the composition is based on several other paintings, supported by study of earlier art and ancient artefacts. With Goldmark it is through the use of tried and tested structures and techniques of melodic development, combined with allusions to well-known works by other composers. Goldmark brings to these familiar features a certain boldness, particularly in terms of his treatment of dissonance. This lends the music a sense of "otherness," which in nineteenth-century Vienna was often defined as "exotic" or "oriental". This "otherness" is essential to understanding Goldmark. Although a Jew with Hungarian origins, Goldmark strove for full integration into Viennese society, to be accepted as German. ${ }^{100}$ This he could only achieve by being true to himself and finding an individual voice, regardless of others' opinions of him. Penthesilea represents one step in this process of integration. It was a daring and original choice of composition which broke the boundaries of decency. Yet it can be fully justified by the artistic milieu in which Goldmark found himself. In certain respects ahead of its time, it was on the cusp of a new artistic world. Herein lie both its difficulty and its fascination. 